\title{
Distribution and availability of arsenic in soils from the industrialized urban area of Beijing, China
}

\author{
Wei Luo ${ }^{a}$, Yonglong Lu ${ }^{\mathrm{a}, *}$, Guang Wang ${ }^{\mathrm{a}}$, Yajuan Shi ${ }^{\mathrm{a}}$, Tieyu Wang ${ }^{\mathrm{a}}$, John P. Giesy ${ }^{\mathrm{b}, \mathrm{c}, \mathrm{d}, \mathrm{e}}$ \\ a State Key Lab of Urban and Regional Ecology, Research Center for Eco-Environmental Sciences, Chinese Academy of Sciences, Beijing 100085, China \\ ${ }^{\mathrm{b}}$ Department of Veterinary Biomedical Sciences and Toxicology Center, University of Saskatchewan, Canada \\ ${ }^{\mathrm{c}}$ Department of Zoology, National Food Safety and Toxicology Center and Center for Integrative Toxicology, Michigan State University, East Lansing, MI 48824, USA \\ ${ }^{\mathrm{d}}$ Department of Biology and Chemistry, City University of Hong Kong, Kowloon, Hong Kong, China \\ e School of Environment, Nanjing University, Nanjing, China
}

\section{A R T I C L E I N F O}

\section{Article history:}

Received 22 October 2007

Received in revised form 21 February 2008

Accepted 4 March 2008

Available online 21 April 2008

\section{Keywords:}

Metalloid

Sequential extraction

Soil pollution

Industrialized

Urban area

Asia

\begin{abstract}
A B S T R A C T
Concentrations of arsenic (As) were determined in soils of 5 industrial sites in an urban area of Beijing, China. Fifty seven typical surface soils were sampled to determine total concentrations of metals, $\mathrm{pH}$ and dissolved organic carbon (DOC). One hundred and eight deep soils were submitted to a four-step, sequential extraction to assess the relative mobility and bioavailability of As in the soil profiles. Total concentrations of As in surface soils ranged from 5.7 to $2.3 \times 10^{1} \mathrm{mg} \mathrm{kg}^{-1}$, dw with greater concentrations inside the perimeter of the chemical plant which had greater concentrations than did other plants. $75.4 \%$ of surface soil samples in the industrial area contained concentrations of As that were greater than was considered to be the background concentration of $7.8 \mathrm{mg} \mathrm{kg}^{-1}$, dw for the region. The mean concentration $\left(9.9 \mathrm{mg} \mathrm{kg}^{-1}, \mathrm{dw}\right)$ in the industrial soils was greater than that soils from other type of land use. Concentrations of As were significantly and negatively correlated with soil pH and DOC in industrial soils. Although mean concentration of total As in the soils from all sites were less at greater depths, the entire range from 0 to $180 \mathrm{~cm}$ (especially $0-80 \mathrm{~cm}$ ) contained concentrations of As that were greater than background. Sequential extractions of soil indicated that only some surface soils had relatively great amount of extractable fraction of As. Most soils had relatively great amount of residual As. This result suggests that most arsenic in Beijing industrial soils should be immobile and of limited bioavailability.
\end{abstract}

(c) 2008 Elsevier Ltd. All rights reserved.

\section{Introduction}

It is common for urban areas in China to be extended as result of economic development. Due to the increased demand for dwellings, industrial sites are being moved from the centers of urban areas to suburbs. People living in communities built on As-contaminated soils are at an increased risk of cancer and other adverse health effects even long after the source is removed because of the immobility and accumulation of arsenic in soil. Soil contamination with a range of contaminants such as metals and metalloids including arsenic (As), PAHs, PCBs and mineral oil affect the health of residents, especially children (Stephens et al., 2004; Wong et al., 2006). Thus, the contamination of industrial sites is a critical environmental issue. Beijing is the capital of China and one of the biggest urban cities in the world and different areas have become contaminated with a wide range of chemicals. Industrial activities in the industrialized area, located in south-east Beijing began in the 1950 s and ended in 2006. One of these contaminants is relatively

\footnotetext{
* Corresponding author. Tel./fax: +86 1062849466

E-mail address: yllu@rcees.ac.cn (Y. Lu).
}

great concentrations of As have been reported to occur in the soils and ground waters in south-east of Beijing, where most industrial activities previously took place (Gao et al., 2004; Wang et al., 2004).

Soils in industrial sites can be contaminated with As due to a number of applications to which As has been put, including electro-photography, catalysts, antifouling paints, dyes and soaps, ceramics, battery plates, optoelectronic devices, semiconductors, pigments, insecticides, herbicides, pressure-treated wood, fossil fuel processing and combustion, fertilizer manufacturing, compounds in wood preservatives, insecticide and pesticide production, and disposal and incineration of industrial waste and mining of arsenic containing ores and smelting (O'Neill, 1990; National Research Council, 1999; Popovic et al., 2001). As can also be released from high temperature processes involved in industrial production, because fossil fuel, which contained high level of arsenic $\left(5.6 \times 1^{-1}-1.6 \times 10^{2} \mathrm{mg} \mathrm{kg}^{-1}\right.$, dw) (He et al., 2002), was the most important energy source for industrial production in Beijing (for example, the annual coal consumption was $2.5 \times 10^{7}$ tons in 2002). Arsenic can also come from sludge from these plants (Wang et al., 2004). For example, at a non-ferrous metallurgical 
industrial site in Reppel, north Belgium, arsenic migrated up to $6 \mathrm{~m}$ beneath the soil surface, with the most contaminated portions occurring within the top $2 \mathrm{~m}$, just above the mean water table (Cappuyns et al., 2002). Although current concentrations of As in the environmental rarely cause morbidity or death in the general population, continued exposure to lesser concentrations of As has been associated with a wide range of adverse effects (Chang, 1996; Nadal et al., 2004). Ingesting or inhaling As-bearing particles may result in bladder, kidney, liver, lung, and skin cancers.

Therefore, a detailed study of surface soils and soil profiles of As in Beijing industrialized area was conducted. Measuring total As is of limited value for assessing environmental samples because the availability, mobility, (phyto)toxicity, and potential risk of arsenic is strongly affected by arsenic speciation (Pongratz, 1998). The European Community Bureau of Reference (BCR) suggests the use of a method that fractionates metals into the operationally defined phases of acid-soluble, reducible, oxidizable and residual, with the steps targeting exchangeable and carbonate bound metals, iron and manganese oxide/hydroxide associated metals, metals bound to sulfide and organic phases, and mineral phases, respectively (Ure et al., 1993). Because this method is more operationally effective than others proposed previously, such as that of Tessier (Fernández et al., 2004), it was used to determine and compare the chemical speciation of arsenic to evaluate its relative mobility and bioavailability in soils of industrial sites.

\section{Materials and methods}

\subsection{Site description}

Five representative industrial sites in the industrialized area located approximately $1-8 \mathrm{~km}$ southeast of downtown Beijing were studied. Each of these areas, denoted as A, B, C, D and E, represent different factory areas. Plant A was established in 1958 and its main products were chemical agents, fluorescent, and photosensitive materials. Plant B was established in 1956 and produced pesticides, PVC plastic, and rubber products. Plant $C$ was built in 1959 and its main products were coke, coal gas, ammonium-sulfate, benzene, naphthalene, and hydroxybenzene. Plants D and E were established, respectively, in 1954 and 1956. Plant D mainly produced pesticides, lacquer, and building and industrial paint, while Plant E mainly produced dyestuffs, paint products, and vitriol. Because some of these factories had arsenical lye desulfurization sections, they may have deposited a large amount of arsenic pollution in the soils. All of the plants have now been closed or moved, and some residential communities have been or will be established on the land. There are also other facilities in the area, such as hospitals, schools, residential communities, restaurants, and guesthouses. The soils in the investigated area developed on a sandy-textured alluvial deposit and are dominated by silt and sandy loams; the predominant soil types are typical fluvial in origin. Sampling points were selected depending on the location of production and waste treatment sectors, which took up most of the site and were potentially important sources of contamination.

\subsection{Sample collection}

Fifty seven representative surface soils and 108 deep layer soil samples from 27 profile pits were collected from five regions (Fig. 1). A representative surface soil sample $(0-10 \mathrm{~cm}$ deep) was made from the 4 sub-samples collected at each sampling point. Samples were taken from each profile pit at depths of $20 \mathrm{~cm}$, $80 \mathrm{~cm}, 180 \mathrm{~cm}$ and $400 \mathrm{~cm}$.

\subsection{Fractionation and quantification}

Soils were characterized by determining the total and 4 extractable fractions of As, $\mathrm{pH}$ and total organic carbon (TOC). Total metals including As were quantified by use of the USEPA Method 3050B (US EPA, 1996a). Prior to analysis, stones and foreign objects were removed by hand, and the soil samples were air-dried at room temperature for a few days, gently crushed in an agate mortar, completely passed through a nylon sieve of 100 meshes $(0.149 \mathrm{~mm})$, and then stored in glass bottles. A four-step chemical extraction procedure was used to separate the As into different phases that represented differential bioavailability. These included the following sequential extractions: ( $0.11 \mathrm{M} \mathrm{HOAc}, 0.1 \mathrm{M} \mathrm{NH}_{2} \mathrm{OH}-$ $\mathrm{HCl}, \mathrm{H}_{2} \mathrm{O}_{2} / 1 \mathrm{M} \mathrm{NH}_{4} \mathrm{OAc}, \mathrm{HF} / \mathrm{HNO}_{3}$ ) (Ure et al., 1993). Total concentrations of metals and 4 extractable fractions of As were determined by inductively coupled plasma-mass spectrometry (ICPMS) which had a detection limit of $0.04 \mathrm{mg} \mathrm{kg}^{-1}$, dw in soil. The accuracy of the instrumental methods and the analytical procedures was determined by testing certified reference materials (GBW07427) obtained from the Center of National Standard Reference Material of China every tenth sample. Precision was estimated by use of analysis of duplicate. Mean recoveries were between $90 \%$ and $110 \%$. Soil $\mathrm{pH}$ was determined by dissolving $15 \mathrm{~g}$ of soil in $15 \mathrm{ml}$ of deionized water, and after mixing for $24 \mathrm{~h}, \mathrm{pH}$ was measured with a $\mathrm{pH}$-meter. DOC,was determined by mixing $7 \mathrm{~g}$ of soil with $28 \mathrm{ml}$ of distilled water for $1 \mathrm{~h}$, and the mixture was centrifuged and filtered through $0.45 \mu \mathrm{m}$ filters (Wright et al., 2005). Extracts were analyzed for DOC by use of the persulfate oxidation using a TOC analyzer (model 7000, OI Corporation, Texas, USA).

\subsection{Statistical treatment}

Statistical analyses were conducted by use of Microsoft Excel and SPSS 10.01 (SPSS Inc., USA). The distributions of concentrations were tested to determine if they approximated the normal probability function with the Kolmogorov-Smirnov method. Concentrations of As from each site were analyzed by one way analysis of variance (ANOVA) to determine if they were different from one another. Differences between means were tested by Turkey's means comparison test for Post Hoc Multiple Comparisons. A significance level of $P<0.05$ was used throughout the study. Correlations between the measured parameters were analyzed by Pearson product-moment correlation.

\section{Results and discussion}

\subsection{Total As in surface soils}

Total concentrations of As in surface soils varied among the industrial sites (Table 1) with mean concentrations in the following decreasing order: $\mathrm{A}>\mathrm{E}>\mathrm{C}>\mathrm{B}>\mathrm{D}$. The mean concentration of arsenic in the soils of Site $A\left(1.4 \times 10^{1} \mathrm{mg} \mathrm{kg}^{-1}, \mathrm{dw}\right)$ was significantly $(P<0.05)$ greater than that at any other site and exceeded the background value of $7.8 \mathrm{mg} \mathrm{kg}^{-1}$, dw. This background As concentration was based on an extensive investigation of the entire Beijing region, in which 120 soil samples were collected from areas absent obvious sources of metals (Chen et al., 2004). Chemical industrial enterprises like Plant $A$, which produced chemical agents and fluorescent and photosensitive materials, present the greatest possibility of adverse effects among these industrial sites. It has been reported that the greatest number of environmental accidents occurred in Plant A. There were no significant differences among As concentrations in the soils of Sites B, C, and D. Although the mean As concentration $\left(8.3 \mathrm{mg} \mathrm{kg}^{-1}, \mathrm{dw}\right.$ ) in soils from Site D 


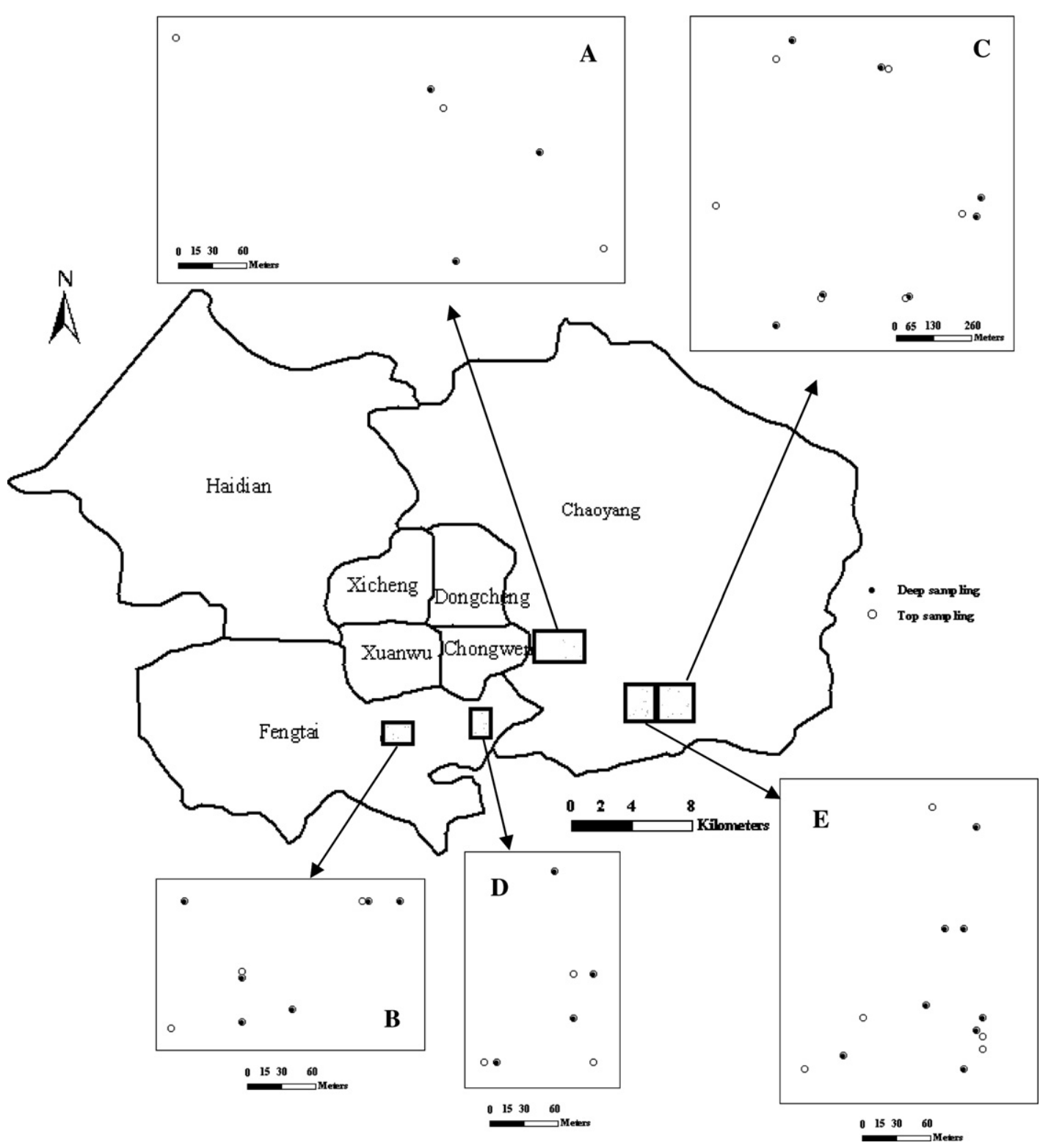

Fig. 1. Sampling scheme at the industrialized urban area of Beijing, China.

Table 1

Descriptive statistics of total arsenic concentrations and mean values of $\mathrm{pH}$ and $\mathrm{DOC}$ in the surface soils

\begin{tabular}{|c|c|c|c|c|c|c|c|c|}
\hline \multirow[t]{2}{*}{ Site } & \multirow[t]{2}{*}{ No. of samples } & \multirow[t]{2}{*}{$\mathrm{pH}$} & \multirow[t]{2}{*}{$\mathrm{DOC}\left(\mathrm{mg} \mathrm{kg}^{-1}\right)$} & \multicolumn{5}{|c|}{ As $\left(\mathrm{mg} \mathrm{kg}^{-1}\right)$} \\
\hline & & & & Mean ${ }^{*}$ & Median & SD & Min. & Max. \\
\hline A & 6 & 8.0 & 375 & $1.4 \times 10^{1, \mathrm{a}}$ & $1.2 \times 10^{1}$ & 4.5 & $1.1 \times 10^{1}$ & $2.3 \times 10^{1}$ \\
\hline B & 13 & 8.2 & 628 & $8.9^{\mathrm{bc}}$ & 8.4 & 2.1 & 6.6 & $1.4 \times 10^{1}$ \\
\hline C & 14 & 8.5 & 523 & $9.6^{\mathrm{bc}}$ & 9.7 & 2.1 & 5.7 & $1.3 \times 10^{1}$ \\
\hline $\mathrm{D}$ & 10 & 8.4 & 484 & $8.3^{\text {bd }}$ & 8.0 & 1.7 & 5.7 & $1.2 \times 10^{1}$ \\
\hline $\mathrm{E}$ & 14 & 8.3 & 585 & $1.1 \times 10^{1, \mathrm{cf}}$ & $1.1 \times 10^{1}$ & 3.0 & 6.4 & $1.7 \times 10^{1}$ \\
\hline
\end{tabular}

* For the indicated elements, those values not showing a common superscript (a, b, c, d, f) are significantly different $(P<0.05)$.

was the least, it still exceeded the background value for Beijing. Therefore, attention should be paid to industrial land, especially to land associated with chemical, dyestuffs, and painting factories.

Concentrations of As in soils from industrial sites were compared with those in non-industrial soils in Beijing (Table 2). The total concentration of As in surface soils from the industrial area ranged from 5.7 to $2.3 \times 10^{1} \mathrm{mg} \mathrm{kg}^{-1}$, dw. The mean concentration of As $\left(9.9 \mathrm{mg} \mathrm{kg}^{-1}, \mathrm{dw}\right)$ in industrial soils was greater than that soils from other types of land use. Most (75.4\%) of the soil samples taken from the industrial area during this study contained concentrations of As that were greater than the area-wide background value (Chen et al., 2004). The median concentration of As in all soils from the industrial areas was $9.7 \mathrm{mg} \mathrm{kg}^{-1}$, dw. The greater heterogeneity among samples within a location, which is captured by the standard deviation values observed (Tables 1 and 2) suggests more human intervention at the industrialize sites. 
Table 2

Comparison of total arsenic concentration in industrial soils with those in nonindustrial soils in Beijing

\begin{tabular}{lllllll}
\hline Land use & $\begin{array}{l}\text { No. of } \\
\text { samples }\end{array}$ & $\begin{array}{l}\text { Concentration } \\
\left(\mathrm{mg} \mathrm{kg}^{-1}\right)\end{array}$ & & \multicolumn{2}{l}{$\begin{array}{l}\text { } \text { Sample above background } \\
\text { value of As }\end{array}$} \\
& & Mean & SD & & $\begin{array}{l}\text { No. of } \\
\text { samples }\end{array}$ & $\begin{array}{l}\text { Percentage } \\
(\%)\end{array}$ \\
\hline Industrial land & 57 & 9.9 & 2.9 & & 43 & 75.4 \\
Vegetable plot $^{\mathrm{a}}$ & 77 & 8.6 & 2.5 & 44 & 57.1 \\
Paddy field $^{\mathrm{a}}$ & 14 & 9.4 & 2.4 & & 12 & 85.7 \\
Orchard land $^{\mathrm{a}}$ & 37 & 8.2 & 2.9 & & 19 & 51.4 \\
Greenbelt land $^{\mathrm{a}}$ & 12 & 8.8 & 2.2 & 7 & 58.3 \\
Corn field $^{\mathrm{a}}$ & 290 & 8.2 & 2.2 & & 157 & 54.1 \\
\hline
\end{tabular}

${ }^{a}$ From Chen et al. (2005).

To assess the potential for non-cancer adverse effects on humans concentrations of As in industrial soils were compared with action, which is also the non-carcinogenic reference limit for residential soil that is thought to be safe for people living in residential areas (21.65 $\mathrm{mg} \mathrm{kg}^{-1}, \mathrm{dw}$ ) (US EPA, 2000). There were only two samples (3.5\% of total) in our study that contained As concentrations that were in excess of the action level. While based on noncancer toxicity it was concluded that the industrialized areas investigated could be developed for residential purposes, the carcinogenic reference limit of residential soil included in the Preliminary Remediation Goals (0.39 $\mathrm{mg} \mathrm{kg}^{-1}$ ) (US EPA, 2000), was exceeded by all of the locations studied. Concentrations of As in all of the soils from industrial locations 14-57-fold greater than the reference limits. Thus, while the concentrations of As observed in the industrial soils would not be expected to cause acute toxicity, long-term exposure to the soils, under the assumptions used to derive the reference value, suggest that these soils could pose cancer risk to human if the industrial sites were developed for residential purpose.

The US EPA-soil screening levels (SSLs) methodology (US EPA, 1996b) was applied to estimate the potential concentration of As that could be expected to occur in a well. According to the Preliminary Remediation Goals methods, generic soil screening levels (SSL) to protect groundwater, if DAF (dilution-attenuation factor) values of 1.0 or 20 (US EPA, 2000) were applied the predicted concentrations in groundwater would be $1.0 \mathrm{mg} \mathrm{kg}^{-1}$ and $29 \mathrm{mg} \mathrm{kg}^{-1}$, respectively. Since concentrations of As in soil samples from all of the industrial sites were greater than $1 \mathrm{mg} \mathrm{kg}^{-1}$, but less than $29 \mathrm{mg} \mathrm{kg}^{-1}$, it was estimated that, although there was dilutionattenuation between the source of arsenic and the receptor well, the contamination source areas would not be up to about $2000 \mathrm{~m}^{2}$. These comparative conditions indirectly confirm the significant hazard for environment and human posed by arsenic in industrial soils. The results presented here also have some implications for managing the conversion of previously used land into land suitable for residential purposes. However, the assumptions of the models and threshold values applied in this analysis were protective and very conservative, if long-term exposure to soils at the site could be minimized with restriction on use or active remediation, the sites could still be used for some residential purposes.

\subsection{Relationships between As, $\mathrm{pH}, \mathrm{DOC}$ and metals}

Mobility of arsenic in surface soils is dependent on various parameters, among which adsorption of arsenate onto soil particles is very important. Arsenate $\left(\mathrm{As}^{5+}\right)$ and arsenite $\left(\mathrm{As}^{3+}\right)$ are the primary forms of inorganic arsenic in soils. Of these forms, $\mathrm{As}^{3+}$ is the most toxic, soluble and mobile species found in the environment while arsenate mobility is quite low in acidic soils. Conversely, in alkaline soils, As in the more soluble Na-arsenate form can be more mobile in soils. Mobility of arsenate and $\mathrm{As}^{3+}$ is a function of their adsorption, which in turn is controlled primarily by $\mathrm{pH}$ (Elkhatib et al., 1984; McBride, 1994). In present study, the concentration of As in soils was negatively correlated with $\mathrm{pH}$ (Table 3 ), implying that as $\mathrm{pH}$ increases, arsenic mobility increases due to releases of As under alkaline conditions $(\mathrm{pH}>8.0)$ (Table 1). Therefore, the arsenic would have short residence time in the soils and tends to move downwards, as $\mathrm{pH}$ increases.

DOC can also be an important factor in controlling mobility of As in soils (Kalbitz and Wennrich, 1998). The complexation of As by organic ligands (DOC) in natural environments prevents sorption and co-precipitation with solid-phase organics and inorganic ligands, which may increase its mobility in aquatic and soil systems. Therefore, leaching by rainfall or snowmelt usually results in transport over only short distances (Welch et al., 1988). In the present study DOC was significantly $(P<0.05)$ and negatively correlated with concentrations of As in soils (Table 3 ). This suggests that DOC is a major controlling factor for arsenic concentration. The relationships of arsenic with $\mathrm{Cr}, \mathrm{Ni}, \mathrm{Zn}, \mathrm{Cd}$, and $\mathrm{Pb}$ suggest that much of the arsenic in the soils comes from the same sources.

\subsection{Total As in soil profiles}

The profile of total concentrations of As decreased as a function of depth from the top soil (Fig. 2). This result is in agreement with the results of other studies (Cappuyns et al., 2002). There was no statistically significant difference in concentrations of As among soils from $20 \mathrm{~cm}, 80 \mathrm{~cm}$ and $180 \mathrm{~cm}$. However, mean concentrations of As at these depths were significantly great than those at

Table 3

Rank correlation coefficients for $\mathrm{pH}, \mathrm{DOC}$ and metals in the soils $(n=57)$ of the Beijing industrialized urban area

\begin{tabular}{llllllllll}
\hline & $\mathrm{DOC}$ & $\mathrm{pH}$ & $\mathrm{Cr}$ & $\mathrm{Cu}$ & $\mathrm{Ni}$ & $\mathrm{Zn}$ & $\mathrm{Cd}$ & $\mathrm{Pb}$ & $\mathrm{As}$ \\
\hline $\mathrm{DOC}$ & 1 & & & & & & & & \\
$\mathrm{pH}$ & 0.33 & 1 & & & & & & & \\
$\mathrm{Cr}$ & -0.18 & 0.04 & 1 & & & & & & \\
$\mathrm{Cu}$ & 0.1 & -0.09 & $0.34^{* *}$ & 1 & & & & & \\
$\mathrm{Ni}$ & $-0.37^{*}$ & $-0.36^{*}$ & $0.61^{* *}$ & 0.2 & 1 & & & & \\
$\mathrm{Zn}$ & -0.21 & -0.17 & $0.54^{* *}$ & $0.31^{*}$ & $0.32^{*}$ & 1 & & & \\
$\mathrm{Cd}$ & -0.32 & -0.26 & $0.31^{*}$ & 0.06 & 0.23 & $0.3^{*}$ & 1 & & \\
$\mathrm{~Pb}$ & -0.06 & -0.3 & $0.45^{* *}$ & 0.07 & $0.36^{* *}$ & $0.42^{* *}$ & 0.14 & 1 & \\
$\mathrm{As}$ & $-0.4^{*}$ & $-0.37^{*}$ & $0.48^{* *}$ & 0.14 & $0.6^{* *}$ & $0.33^{*}$ & $0.4^{*}$ & $0.63^{* *}$ & 1 \\
\hline
\end{tabular}

* Correlation is significant at the 0.05 level (2-tailed).

* Correlation is significant at the 0.01 level (2-tailed).

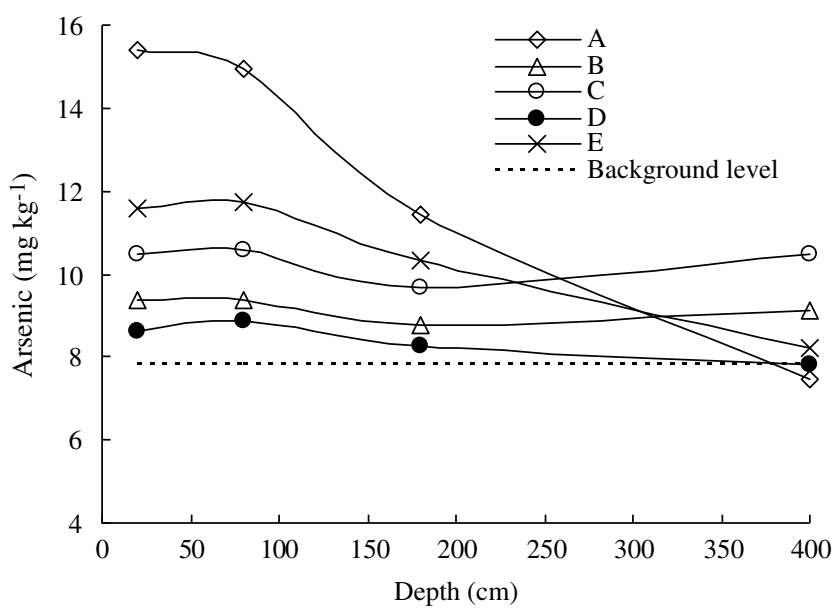

Fig. 2. Arsenic concentration profiles with depth from different sites. 
Table 4

Descriptive statistics of arsenic concentrations at different depths of soils in the industrial area

\begin{tabular}{llllll}
\hline $\begin{array}{l}\text { Depth } \\
(\mathrm{cm})\end{array}$ & $\begin{array}{l}\text { No. of } \\
\text { samples }\end{array}$ & $\begin{array}{l}\text { Minimum } \\
\left(\mathrm{mg} \mathrm{kg}^{-1}\right)\end{array}$ & $\begin{array}{l}\text { Maximum } \\
\left(\mathrm{mg} \mathrm{kg}^{-1}\right)\end{array}$ & $\begin{array}{l}\text { Mean } \\
\left(\mathrm{mg} \mathrm{kg}^{-1}\right)\end{array}$ & $\begin{array}{l}\mathrm{SD} \\
\left(\mathrm{mg} \mathrm{kg}^{-1}\right)\end{array}$ \\
\hline 20 & 27 & 5.7 & $2.3 \times 10^{1}$ & $1.1 \times 10^{1, \mathrm{a}}$ & 3.5 \\
80 & 27 & 5.3 & $2.5 \times 10^{1}$ & $1.1 \times 10^{1, \mathrm{a}}$ & 3.6 \\
180 & 27 & 5.6 & $1.8 \times 10^{1}$ & $9.9^{\mathrm{a}}$ & 3.1 \\
400 & 27 & 3.7 & $1.8 \times 10^{1}$ & $8.8^{\mathrm{b}}$ & 3.7 \\
\hline
\end{tabular}

For the indicated elements, those values not showing a common superscript $(\mathrm{a}, \mathrm{b})$ are significantly different $(P<0.05)$.

$400 \mathrm{~cm}$ (Table 4). The mean concentration of As for most sites decreased dramatically below $180 \mathrm{~cm}$, and, at Site A, at $400 \mathrm{~cm}$ below the surface, the concentration was not significantly different from background (Fig. 2). Because the concentrations of As in some soils at $0-80 \mathrm{~cm}$ exceeded the residential soil guideline for protection of human health, which is $20 \mathrm{mg} \mathrm{kg}^{-1}$, dw, some remedial restoration actions should be taken. Moreover, the mean concentrations of arsenic at $0-400 \mathrm{~cm}$ were still higher than the background concentration for most sites. The depth profile of As contaminations suggests that contamination took place at approximately 0 $400 \mathrm{~cm}$ and that some movement of arsenic might have occurred down to at least $400 \mathrm{~cm}$ due to leaching. Although these five plants had almost the same period of production, they had different distributions of arsenic concentration in deep soils. The fact that Site A had the greatest number of environmental accidents may be the reason for the great variation of arsenic concentration in the soil profile.

\subsection{As speciation in soil profiles}

Understanding the speciation of As can help assess how strongly it is retained in soil and how easily it may be released into soil solution. The relative amounts of arsenic in each fraction, expressed as a percentage of the cumulative total extracted from any given soil sample, are presented (Table 5). The proportion of HAc-soluble As was generally greater in surface horizons and de-

Table 5

Mean sequential extraction results of arsenic of industrialized urban soils at different depths of profile for different sites, given in \% of total concentration

\begin{tabular}{|c|c|c|c|c|c|}
\hline \multirow[t]{2}{*}{ Site } & \multirow[t]{2}{*}{ Fraction } & \multicolumn{4}{|c|}{ Extraction yield at different depths (\%) } \\
\hline & & $20 \mathrm{~cm}$ & $80 \mathrm{~cm}$ & $180 \mathrm{~cm}$ & $400 \mathrm{~cm}$ \\
\hline \multirow[t]{4}{*}{ A } & HAc-soluble & $8.8(2.5)$ & $9.1(2.6)$ & $8.2(2.3)$ & $7.7(2.0)$ \\
\hline & Reducible & $32.3(9.7)$ & $27.9(7.9)$ & $16.2(4.1)$ & $12.1(3.0)$ \\
\hline & Oxidizable & $24.4(7.2)$ & $21.8(6.0)$ & $13.5(3.2)$ & $10.3(2.1)$ \\
\hline & Residual & $34.5(1.0)$ & $41.2(1.2)$ & $62.1(1.9)$ & $69.9(2.1)$ \\
\hline \multirow[t]{4}{*}{ B } & HAc-soluble & $6.2(1.6)$ & $6.3(1.6)$ & $5.1(1.3)$ & $4.7(1.2)$ \\
\hline & Reducible & $16.3(3.7)$ & $15.7(3.5)$ & $10.3(2.0)$ & $15.4(3.5)$ \\
\hline & Oxidizable & $10.2(2.2)$ & $9.9(2.1)$ & $7.4(1.5)$ & $8.3(1.8)$ \\
\hline & Residual & $67.3(2.5)$ & $68.1(2.4)$ & $77.2(3.8)$ & $71.6(3.5)$ \\
\hline \multirow[t]{4}{*}{ C } & HAc-soluble & $7.3(1.9)$ & 7.2(1.9) & $6.5(1.7)$ & $7.3(1.9)$ \\
\hline & Reducible & $19.9(4.9)$ & $18.7(4.5)$ & $14(3.3)$ & $19.1(4.9)$ \\
\hline & Oxidizable & $15.4(3.8)$ & $14.8(3.7)$ & $11.3(2.6)$ & $14.2(3.7)$ \\
\hline & Residual & $57.4(1.7)$ & $59.3(1.8)$ & $68.2(2.0)$ & $59.4(1.8)$ \\
\hline \multirow[t]{4}{*}{$\mathrm{D}$} & HAc-soluble & $5.1(1.3)$ & $4.7(1.0)$ & $3(0.7)$ & $2.1(0.5)$ \\
\hline & Reducible & $11.4(2.4)$ & $12.6(3.0)$ & $9.7(2.0)$ & $8.4(1.7)$ \\
\hline & Oxidizable & $4.9(0.3)$ & $5(0.3)$ & $4.1(0.3)$ & $3.3(0.2)$ \\
\hline & Residual & $78.6(3.8)$ & $77.7(3.8)$ & $83.2(4.1)$ & $86.2(4.2)$ \\
\hline \multirow[t]{4}{*}{$\mathrm{E}$} & HAc-soluble & $7.8(2.3)$ & $7.9(2.3)$ & $7.1(1.8)$ & $7.7(2.2)$ \\
\hline & Reducible & $23.7(6.1)$ & $24(6.2)$ & $18.6(4.7)$ & $15.2(3.7)$ \\
\hline & Oxidizable & $20.1(5.4)$ & $21.4((5.8)$ & $16.6(4.4)$ & $14.1(3.8)$ \\
\hline & Residual & $48.4(1.5)$ & $46.7(1.4)$ & $57.7(1.8)$ & $63(1.9)$ \\
\hline
\end{tabular}

The values in parenthesis give the SD, for example, 5.1(1) means $5.1 \pm 1$. creased as a function of depth. The fact that the HAc-soluble As fraction represented a relatively small proportion of the total As in most samples, demonstrates the relatively greater mobility and bioavailability (especially phytotoxicity) of this fraction. Thus, the potential pollution risk for groundwater and plants is ordered as follows: $\mathrm{A}>\mathrm{E}>\mathrm{C}>\mathrm{B}>\mathrm{D}$. This suggests that As was more mobile in the more contaminated soils (such as Site A) than in less contaminated soils (such as Site D). These results agree with the view that metals from anthropogenic sources are more mobile than those from soil parent materials (Chlopecka et al., 1996). Proportions of extraction of reducible As were relatively great in most of the soils (Table 5). The order of proportions of this fraction of the total As was: A $>$ E $>$ C $>$ B $>$ D. The extractability of reducible As increased with the level of soil contamination. The relative proportion of oxidizable As in soils from Site A was less than that at Site $D$, which can be explained by differences in chemical characteristics among sites. The oxidizable fraction of arsenic decreased as the depth increased. Reduction and oxidation states of As are also important, since these properties influence the transformation of As into bioavailable states in response to changing soil properties, such as pH. Most As was associated with the residual fraction, which is very immobile and of limited bioavailability. The proportion of As associated with the residual fraction increased as profile depth increased, which agrees with the results of McLaren et al. (1998). This finding indicates that the arsenic-bearing phases present in the deep soils are more stable and less biologically available. It is common for a greater proportion of the total arsenic present in historically polluted soils to be extracted only from the residual fraction (Voigt et al., 1996). The greater proportion of residual As in the top layer most likely reflects the original pollutant's dry deposition, some of which has leached down the profile. Most As in soils of Site $\mathrm{D}$ is relatively immobile because the largest percentage of arsenic was found in the residual fraction (78.6\%). This suggests that the major presence of As is in the residual phases of less As-contaminated soils. However, in the presence of leachate and water, these slightly contaminated soils may dissolve, releasing As. Regardless, the residual material represents a long-term source of As in the environment as the minerals are slowly oxidized, especially in extremely contaminated soils.

\section{Conclusion}

Concentrations of As in all soils within the industrialized urban areas were elevated relative to background concentrations determined for the Beijing metropolitan region. Concentrations of As were particularly great in soils from the chemical plant. Some soils at depths of $0-80 \mathrm{~cm}$ contained As concentrations that exceeded the reference limit for residential soil based on carcinogenicity. This result indicates that remedial actions will be necessary at these sites before further development as residential areas can proceed. Soil arsenic concentrations decrease as a function of depth increases. In the industrial area, most soils between $0 \mathrm{~cm}$ and $180 \mathrm{~cm}$ were contaminated with As. Concentrations of As in the industrial soils were significantly and negatively correlated with both $\mathrm{pH}$ and DOC. However, based on a four-step sequential extraction procedure, we can deduce that apart from the arsenic in some surface soils, most arsenic in the industrial soils of Beijing should pose very limited environmental and health risk.

\section{Acknowledgements}

This research was supported by the National Basic Research Program (called the "973" Research Program) with Grant No. 2007CB407307 and the Knowledge Innovation Programs of the Chinese Academy of Sciences, with Grant Nos. KZCX2-YW-420-5 
and KZCX1-YW-06-05-02. The authors also thank the two anonymous reviewers and the editors for the comments on this paper.

\section{References}

Cappuyns, V., Van Herreweghe, S., Swennen, R., Ottenburgs, R., Deckers, J., 2002. Arsenic pollution at the industrial site of Reppel-Bocholt (north Belgium). Sci. Total Environ. 295, 217-240.

Chang, L., 1996. Toxicology of Metals. CRC Lewis Publishers, Boca Raton, FL.

Chen, T.B., Zheng, Y.M., Chen, H., Zheng, G.D., 2004. Background concentrations of soil heavy metals in Beijing. Environ. Sci. 25, 117-122 (in Chinese).

Chen, T.B., Zhen, Y.M., Chen, H., Wu, H.T., Zhou, J.L., Luo, J.F., Zheng, G.D., 2005. Arsenic accumulation in soils for different land use types in Beijing. Geog. Res. 24, 229-235 (in Chinese).

Chlopecka, A., Bacon, J.R., Wilson, M.J., Kay, J., 1996. Forms of cadmium, lead and zinc in contaminated soils from southwest Poland. J. Environ. Qual. 25, 69-79.

Elkhatib, E.A., Bennet, O.L., Wright, R.J., 1984. Kinetics of arsenite sorption in soils. Soil Sci. Soc. Am. J. 48, 758-762.

Fernández, E., Jiménez, R., Lallena, A.M., Aguilar, J., 2004. Evaluation of the BCR sequential extraction procedure applied for two unpolluted Spanish soils. Environ. Pollut. 131, 355-364.

Gao, J.J., Zhang, L.P., Huang, S.B., Ma, M., Wang, Z.J., 2004. Preliminary health risk assessment of heavy metals in drinking waters in Beijing. Environ. Sci. 25, 4750 (in Chinese).

He, B., Liang, L., Jiang, G., 2002. Distribution of arsenic and selenium in selected Chinese coal mines. Sci. Total Environ. 296, 19-26.

Kalbitz, K., Wennrich, R., 1998. Mobilization of heavy metals and arsenic in polluted wetland soils and its dependence on dissolved organic matter. Sci. Total Environ. 209, 27-39.

McBride, M.B., 1994. Environmental Chemistry of Soils. Oxford Univ. Press, New York.

McLaren, R.G., Naidu, R., Smith, J., Tiller, K.G., 1998. Fractionation and distribution of arsenic in soils contaminated by cattle dip. J. Environ. Qual. 27, 348-354.

Nadal, M., Schuhmacher, M., Domingo, J.L., 2004. Metal pollution of soils and vegetation in an area with petrochemical industry. Sci. Total Environ. 321, 59-69.
National Research Council, 1999. Arsenic in Drinking Water. The National Academies Press, Washington, DC.

O’Neill, P., 1990. Arsenic. In: Alloway, B.J. (Ed.), Heavy Metals in Soils. John Wiley \& Sons, New York, pp. 83-99.

Pongratz, R., 1998. Arsenic speciation in environmental samples of contaminated soil. Sci. Total Environ. 224, 133-144.

Popovic, A., Djordjevic, D., Polic, P., 2001. Trace and major element pollution originating from coal ash suspension and transport processes. Environ. Int. 26 251-252.

Stephens, C., Hough, R., Busby, A., Edwards, D., 2004. Assessing the Health Risk and Impact Associated with Living on the Thames View Estate. London School of Hygiene \& Tropical Medicine, London.

Ure, A., Quevauviller, Ph., Muntau, H., Griepink, B., 1993. Speciation of heavy metals in soils and sediments, an account of the improvement and harmonisation of extraction techniques undertaken under the auspices of the BCR of the commission of the European communities. Int. J. Environ. Anal. Chem. 51, 135-151.

US EPA, 1996a. Test Methods for Evaluating Solid waste, SW 846, third ed. Office of Solid Waste and Emergency Response, Washington, DC.

US EPA,1996b. Soil Screening Guidance: Technical Background Document. (TBD) EPA/540/R-95/128, Office of Emergency and Remedial Response, Washington, DC.

US EPA, 2000. Region 9, Preliminary Remediation Goals. <http://www.epa.gov/ region09/waste/sfund/prg/>.

Voigt, D.E., Brantle, S.L., Hennet, R.J.C., 1996. Chemical fixation of arsenic in contaminated soils. Appl. Geochem. 11, 633-643.

Wang, Y.P., Pei, T., Xu, C.X., Chen, D.X., 2004. Research on the accumulative layers of As and $\mathrm{Hg}$ elements in columnar Profile of Soil in Beijing City. Acta Sedimentol. Sinica 22 (Suppl.), 135-139.

Welch, A.H., Lico, M.S., Hughes, J.L., 1988. Arsenic in groundwater of the western United States. Groundwater 26, 333-347.

Wong, C.S.C., Li, X., Thornton, I., 2006. Urban environmental geochemistry of trace metals. Environ. Pollut. 142, 1-16.

Wright, A.L., Provin, T.L., Hons, F.M., Zuberer, D.A., White, R.H., 2005. Dissolved organic $C$ in compost-amended bermudagrass turf. HortScience 40 830-835. 